\title{
The Impact of Vagaries of Nature and Institutions on Fastening Agricultural Economic Growth in Ethiopia
}

\author{
Hassen Beshir \\ Department of Agricultural Economics, Wollo University
}

\begin{abstract}
The main objective of this study is to estimate the production function of Ethiopian's Agriculture sector and identify key factors that plays role in the economy using 1965 - 2014 data. Are there impacts of institutional transformation from public to private ownership of resources in improving agricultural growth? What are the sources of Agricultural productivity growth? Are there productivity changes in the performance of the agriculture sector during the period of 1965 -2014. Aggregate production functions are specified by different economists for estimation. The major are CES and Cobb-Douglas. Cobb-Douglas production function is used to estimate the aggregate production of Ethiopian agricultural sector. In estimating aggregate production function for a country, it is better to consider the co-integration of variables in a time series analysis. In this empirical work, after determining the order of the vector autoregressive, co-integration test is conducted. Thereafter the structural longrun relationships of the variables are identified using vector error correction model. To this end a neoclassical and structuralist model of production function is developed. The result confirms that the variables are co-integrated at polynomial rank of order (2). The variables of production function are non-stationary at their level but stationary after differencing. The Engle Granger causality modeling shows that agricultural labor and Price of agricultural goods to non-agricultural goods Granger Cause agricultural productivity, Capital inputs in agriculture and Price of agricultural goods to non-agricultural goods Granger Cause agricultural labor, Rainfall Granger Cause ratio of Price of agricultural goods to non-agricultural goods and finally ratio of Price of agricultural goods to nonagricultural goods Granger Cause institutional capability. From the vector error correction model result, the coefficient of the co-integrating equation tells that about 45 percent of disequilibrium corrected each year by change in aggregate agricultural production. The overall performance of the model is well fitted, because the $64 \%$ of total variation of the dependent variable is explained by the independent variables included in the model. Moreover, the model selection criteria indicated the model is adequate to represent the real world and manageable to predict agricultural production behavior in Ethiopia. Vector error correction modeling of the sector shows that the Ethiopian agricultural sector is mainly dependent up on institutional capability, price ratio and rainfall in the long run. In the short run, it is determined by agricultural labor, previous agricultural production and rainfall. Finally, forecasting of the agricultural production and its associated sources of growth has been made to provide solution in future values. To circumvent the poverty trap in the country, therefore, the government needs to invest on human capital and irrigation development to reduce its dependence on vagaries of nature. Moreover, competent private-public partnership in increasing the capability of institutions on coordination and cooperation of resource use is also vital. There should be a tradeoff between private-public ownership and likewise between efficiency equity in improving public welfare in Ethiopia.
\end{abstract}

Keywords: Error correction model, Cointegration, Aggregate production function, Short and Long run, Ethiopia. DOI: $10.7176 / \mathrm{JESD} / 10-23-01$

Publication date: December $31^{\text {st }} 2019$

\section{INTRODUCTION}

The agriculture sector is characterized by a wide range of different production systems with varying input usage. The spatial distribution of these systems is heavily influenced by physical aspects of the operating environment of Ethiopian smallholder farmers, namely climatic conditions, water availability, soil and topographical conditions and proximity to markets. Because most agricultural production systems rely heavily on the condition and productivity of the natural resource base, the management practices of farmers (including soil, fodder and water management) can exert an important influence on the sustainability of Ethiopian's natural resource base. A number of studies have also demonstrated that policies that encourage sustainable farm and environmental management practices are likely to be important for the future performance of the agricultural sector. Agricultural activities are different to production systems elsewhere in the economy. Many of these physical and biological factors, such as variations in rainfall and the onset of disease, are largely outside the control of farmers, yet they can have a significant effect on the level of production, input use, prices and the performance of farms. The Agricultural sector is highly affected by erratic rain fall distribution. It is the backbone of the economy; it accounts for almost 38.5$42 \%$ of the gross domestic product (GDP), $80 \%$ of export and $80 \%$ the labor force; and 80 percent of the population lives in rural areas in the current periods. 
Table 1. Transformation of sectors from 1953-2016

\begin{tabular}{|l|c|c|}
\hline \multirow{2}{*}{ Sector to GDP } & \multicolumn{2}{|c|}{ Contribution to GDP in \% } \\
\cline { 2 - 3 } & 1953 & 2016 \\
\hline Agriculture & 76 & 40 \\
\hline Manufacturing and Construction & 7 & 14 \\
\hline Service & 17 & 46 \\
\hline
\end{tabular}

Source: Own Results (2017)

The main objective of this study is to estimate the production function of Ethiopian's Agriculture sector and identify key factors plays role in the economy 1965 - 2014. The study tries to answer:

- Are there impacts of institutional transformation from public to private ownership of resources in improving agricultural growth?

- What are the sources of Agricultural productivity growth?

- Are there productivity changes in the performance of the agriculture sector during the period of 1965 2014 ?

Aggregate production functions are specified by different economists for estimation. The major ones are CES and Cobb-Douglas. Cobb-Douglas production function is used to estimate the aggregate production of Ethiopian agricultural sector. In estimating aggregate production function for a country, it is better to consider the cointegration of variables in a time series analysis. In this empirical work, after determining the order of the vector autoregressive, co-integration test is conducted. Thereafter the structural long-run relationships of the variables are identified using error correction model. The paper is organized as follows. Section two discusses the theoretical models in aggregate production function. Section three presents empirical results of model estimation. Section four concludes.

\section{THEORETICAL MODEL FOR AGGREGATE PRODUCTION FUNCTION}

In specifying the model different school of macro-modelers has used different approaches. In a macroeconomics context, after the Solow-Swan model, growth theory extensively employs aggregate production function and its parameters to come up with important conclusions (Alemayehu and Daniel, 2008). Mankiw et al (1992) used a Cobb-Douglas production function to test the implications of the Solow model while Easterly and Levin (2001) used it for their growth accounting analysis on the relative importance of total factor productivity visa vise total factor accumulation. Building on a neoclassical production function framework, the Solow model highlights the impact on growth of saving, population growth and technological progress in a closed economy setting without a government sector.

The Solow-Swan model used production function with labour and capital as endogenous inputs and technology as exogenous. The Solow growth model is built around the neoclassical aggregate production function and focuses on the proximate causes of growth: $Y=\operatorname{AtF}(K, L)$ where $Y$ is real output, $K$ is capital, $L$ is the labour input and $A t$ is a measure of technology (that is, the way that inputs to the production function can be transformed into output) which is exogenous and taken simply to depend on time. Sometimes, At is called 'total factor productivity'.

The endogenous growth model of Paul Romer used production function with labour and capital as endogenous inputs and technology as endogenous. Paul Romer's (1986) model can be illustrated by modifying the production function. The production function includes technology $(A)$ as an endogenous input: $Y=F(K, L, A)$

Dani Rodrik (2003) has provided a useful framework for highlighting the distinction between the proximate and fundamental determinants of economic growth. Figure 1 provides the model of specification of a production function. 


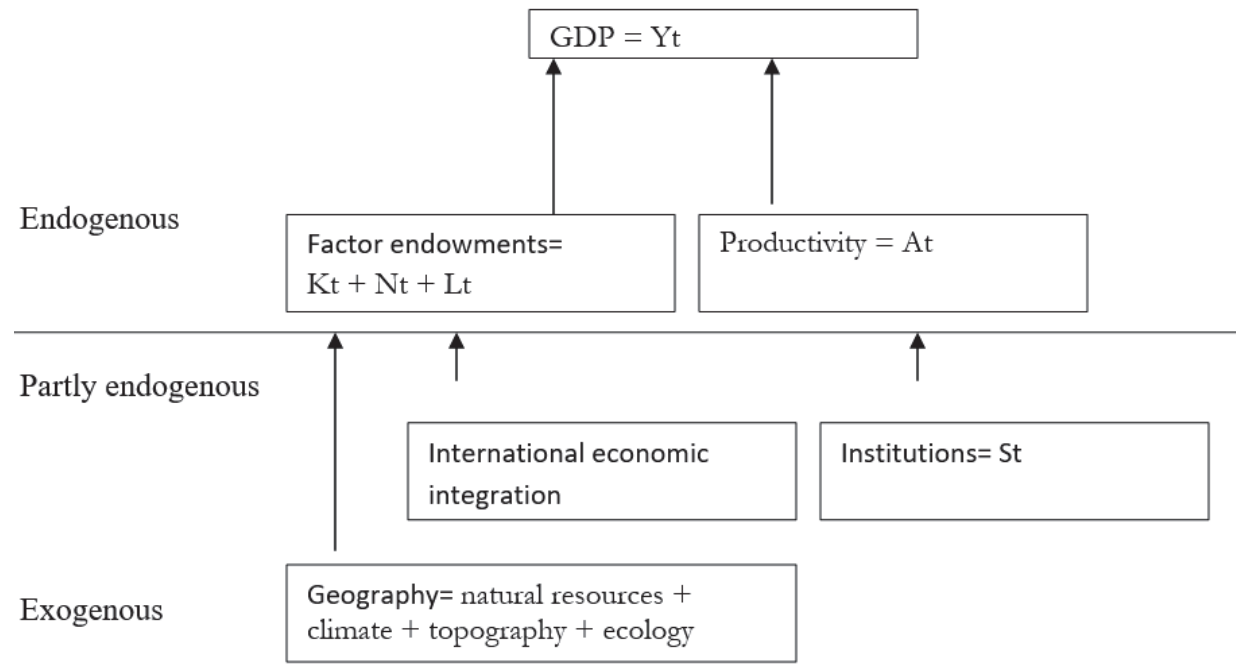

Figure 1 Proximate and fundamental sources of growth

The proximate determinants of growth which is output being directly influenced by an economy's endowments of labour $(\mathrm{Lt})$, physical capital $(\mathrm{Kt})$, natural resources $(\mathrm{Nt})$ and the productivity of these resources (At).

The major fundamental determinant of economic growth in his model includes international economic integration, institutions (social capability) and geography (natural resources, climate, topography, ecology). Social capability refers to the various institutional arrangements which set the framework for the conduct of productive economic activities and without which market economies cannot function efficiently.

Institutions provide a structure within which repeated human interaction can take place, they support market transactions, they help to transmit information between economic agents and they give people the incentives necessary to engage in productive activities (North, 1991).

Given this pedigree, economists have tended to centre their analysis of the deeper determinants of growth on the role of institutions. Emphasis is placed on factors such as the role of property rights, the effectiveness of the legal system, corruption, regulatory structures and the quality of governance (North, 1990; World Bank, 1997; Olson, 2000; Acemoglu et al., 2001, 2002; Glaeser and Shleifer, 2002)

On the other hand, various writers suggest the nonexistence of aggregate production function when there is aggregation in input (Temple, 2008; Shaikh, 1974). They are arguing that if inputs aggregated in the GDP and are used again as input in the specified production function, the production function is humbug. To circumvent such problem, transformation of levels into log, unit roots test and other remedies were employed.

Based on this information, the aggregate production function of Ethiopian agriculture is specified as $\mathrm{Yt}=\mathrm{A}_{\mathrm{t}} \mathrm{Kt}^{\alpha} \mathrm{Lt}^{\beta} \mathrm{e}^{\delta 1 \mathrm{X} 1+\delta 2 \mathrm{X} 2+\delta 3 \mathrm{X} 3+\mathrm{Ut}}$

where $Y_{t}$ is agricultural GDP at time $t$ in Birr, $A_{t}$ is technology used to transform labour and capital into agricultural GDP at time $t, K_{t}$ is capital stock in Birr at time $t, L_{t}$ is agricultural labour employed in man days at time $t, X 1$ is rainfall in millilitre at time $t, X 2$ is price of agricultural product to price of non-agricultural product at time t, X3 stands for institutional capability of the country with the rest of the world at time t, e is exponential function, $U_{t}$ is the disturbance term for measurement error, missed variables and others at time $t$ and $\alpha, \delta$ and $\beta$ are parameters for Cobb-Douglas production function.

This function is preferred for the reason that labour and capital are hypothesized as the major endogenous resources that can be used for the production of agriculture in Ethiopia. Whereas it is hypothesised that rainfall, institutions and price are exogenous to the producers. That is rainfall depend on vagaries of nature which is not under the control of the producer. Farmers are considered as price takers. Institutional capability refers to regime shift from market economy to command economy which is not under the control of producers too. For this reason the model considered rainfall, institutions and price as exogenous for the producers in that they have nothing to do with the technology. Institution is used as dummy variable; it is one if there is open market economy and zero other wise. The dergue period is labelled as zero and the rest one. In natural logarithmic form the equation can be rewritten as:

$\ln \mathrm{Y}_{\mathrm{t}}=\ln \mathrm{A}_{\mathrm{t}}+\ln \mathrm{K}_{\mathrm{t}}+\ln \mathrm{L}_{\mathrm{t}}+\delta 1 \mathrm{X} 1+\delta 2 \mathrm{X} 2+\delta 3 \mathrm{X} 3+\mathrm{Ut}$

Using equation (2) we can estimate the parameters of interest. This is done in the next section.

\section{DATA REQUIREMENT AND EMPIRICAL RESULTS OF MODEL ESTIMATION}

The main source of data for this study is the national income accounts of Ethiopia as prepared and compiled by 
the Ministry of Finance and Economic Development (MOFED), Department of National Accounts. In addition, Ethiopian Economics Association (EEA), World Bank Africa database and National Bank of Ethiopia data are used when it is required. If data are available for long period of time, it is fairly long enough to analyze and use a co-integration of nine to ten variables with the reasonable lags. Hence scarcity of data for such period limits the study to analyze only for four to six variables with reasonable lag length.

Growth Rate of Total Factor Productivity (TFP), Labor (valb) and Land (vald) productivity

The annual compound growth rate of labor, land and TFP varied with fluctuation and situation of rainfall from 1961 to 2012 (see Figure 1).

Figure 1. Annual Growth Rate of TFP, Labor and land and other factors productivity in Ethiopia

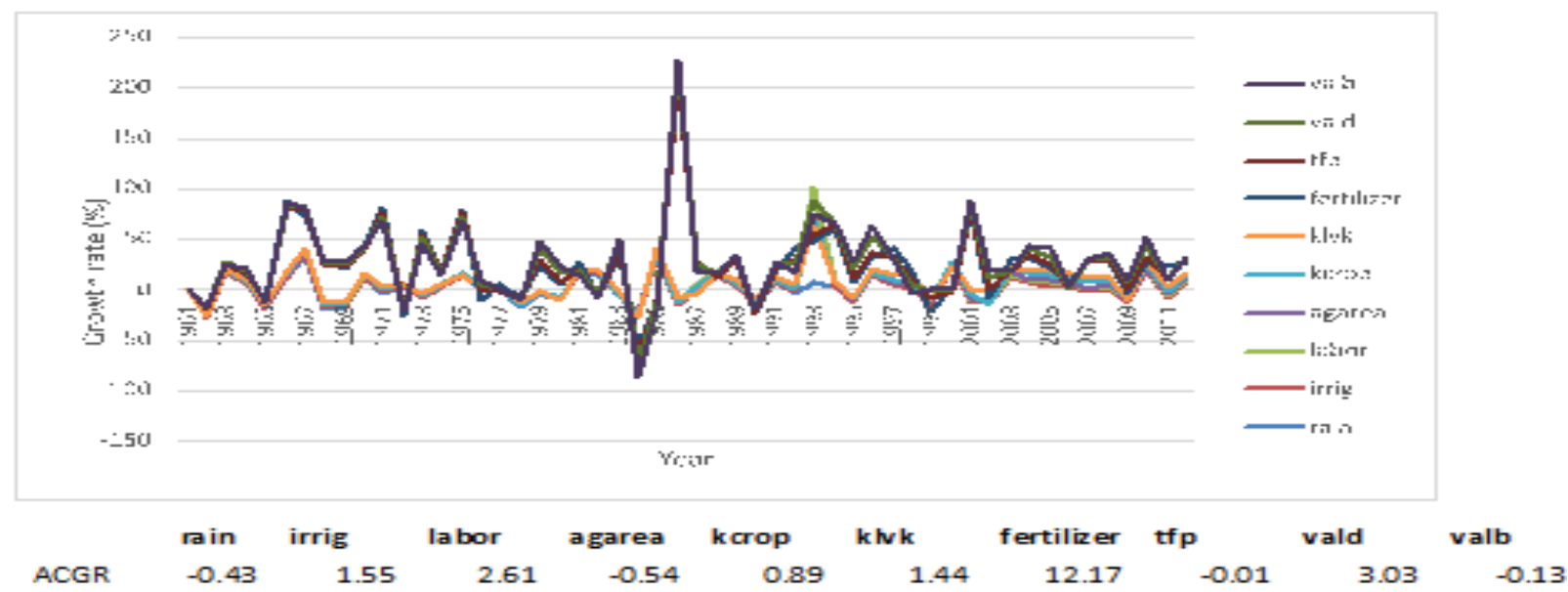

Source: Own Results (2017)

The compound growth rate of irrigation expanded, rainfall, fertilizer applied, labour employed and agricultural area utilized was $1.55,-0.43,12.17,2.62$ and -0.54 percent, respectively. The value of crop (kcrop) and livestock (klvk) compound growth rate was 0.89 and 1.44 percent, respectively. The results confirmed that the major inputs that grows higher was fertilizer application. Based on these application and preconditions, the average annual compound growth rate (ACGR) for TFP, labour and land productivity was $-0.01,-0.13$ and 3.03 percent, respectively. This implied that agricultural and labour productivity and transformation was slow and weak implying a need to transform a capital intensive technology for better TFP.

Figure 2. Annual Growth rate of Rainf all, labour (lagr) and capital (CAPagr) and Production (Agri)

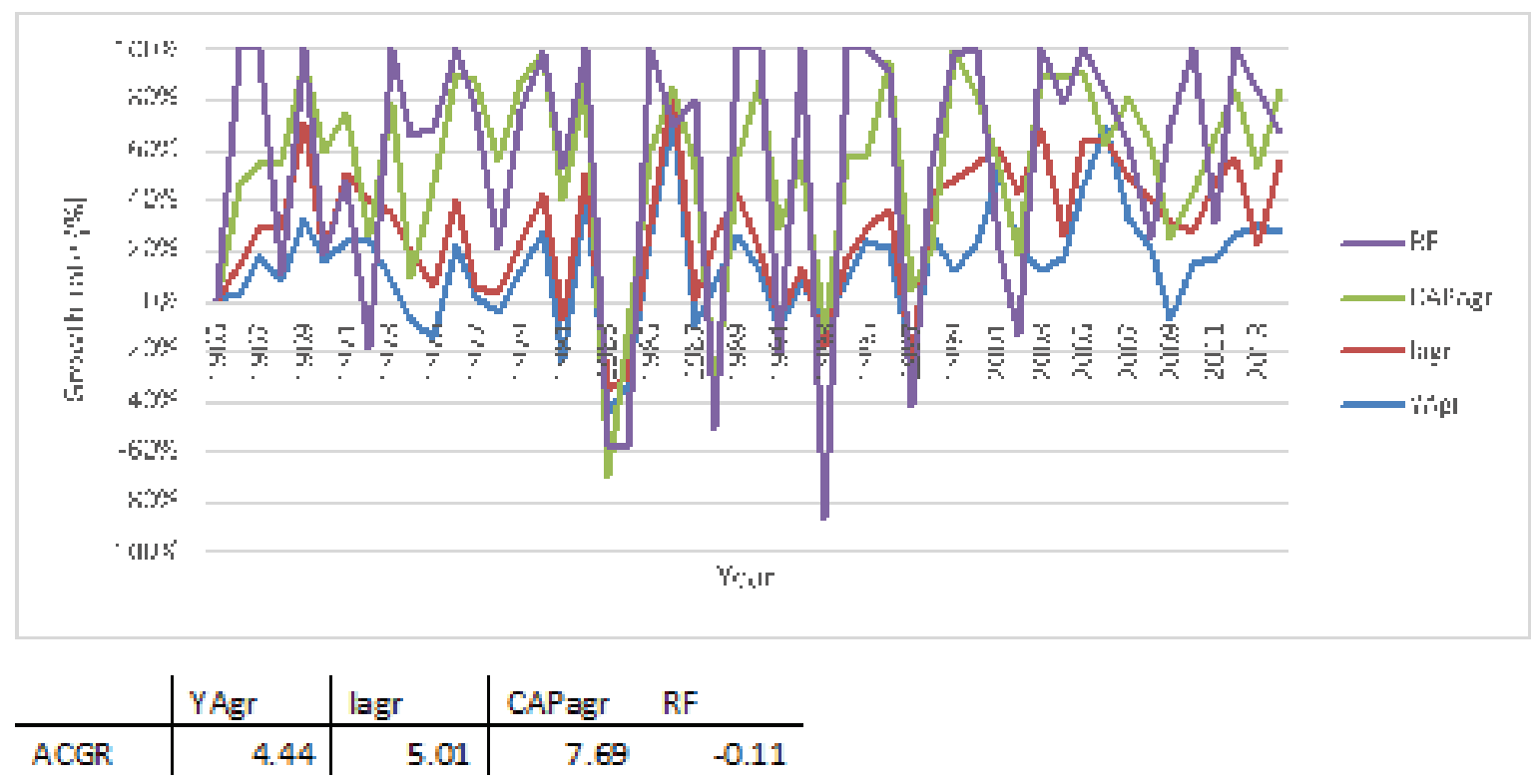

Source: Own Results (2017)

Agricultural production in Ethiopia describes the volatility of rainfall highly influences its resource use, and 
output (Figure 2). The compound growth rate of rainfall over six decades is negative implying a reform on intensifying irrigation through ground and surface methods of water resource use.

The presence of a unit root in macroeconomic variables is not uncommon in time series analysis. If left uncorrected, this will lead to the problem of spurious regression when there is need to model relationships suggested by a researcher (Alemayehu et al 2008). Differencing the I(1) series would tackle the non-stationary problem. However, you would lose the long-run information in the data, which is central to your theoretical model. Thus, you need to think of a mechanism by which you can tackle the problem of spurious regression and have the long-run information as well. This is managed by specifying vector error correction model. The first step in a time series analysis is to conduct unit root test for the variables. The formula to undertake stationarity test in macro variables is defined as follows:

$$
\Delta \mathrm{X}_{t}=\phi_{0}+\beta_{1} \mathrm{X}_{t-1}+\delta t+\sum_{i=1}^{n} \theta_{i} \Delta \mathrm{X}_{t-1}+\varepsilon_{t}
$$

Where $\mathrm{X}$ stands for the variables of interest for example Agricultural GDP and $\Delta$ stands for difference operator and $\theta$ and $\beta$ are parameters to be estimated.

ADF(Dickey and Fuller, 1981) test statistics indicate that all variables are nonstationary at their level but stationary after first differencing (Table 1).

Table 1 Unit root results of variables

\begin{tabular}{lccccc}
\hline & \multicolumn{5}{c}{ ADF Test Statistic } \\
\cline { 2 - 5 } Type & $\mathrm{Y}$ & $\mathrm{L}$ & $\mathrm{K}$ & $\mathrm{RF}$ & $\mathrm{P}$ \\
\hline Level & 1.238557 & 2.45776 & 1.082607 & -3.1081 & 0.803812 \\
Difference & -5.72361 & -3.68889 & -4.35906 & -6.9569 & -5.87648 \\
\hline $1 \%$ Critical Value* & & -3.6117 & & \\
$5 \%$ Critical Value & & -2.9399 & & \\
$10 \%$ Critical Value & & -2.608 & & \\
\hline
\end{tabular}

Source: Own Results (2017)

In this empirical work, to take care of the non-stationarity of the variables and confirm whether there exists a long run equilibrium relationship, the co-integration concept based on Johansen's approach is used (Johansen, and Juselius, 1990 and Johansen, 1991). This concept basically refers to the condition that even if individual series are non-stationary, if there exists a linear combination of $\mathrm{I}(\mathrm{p})$ series in the regression equation, then the regression is not a spurious regression. There are two basic ways of testing the existence of co-integration between variables of interest and estimating the co-integrating vector which are the Engel-Granger and the Johansen Approach. The later approach helps to do with multivariate test and followed in this empirical work.

The johansen approach performs a test for non-zero eigen values which is tantamount to the test for the rank of a matrix, which in turn is a test for the number of co-integration vectors (Alemayehu et al, 2008). First I have estimated unrestricted VAR to determine the lag length. The appropriate lag length in this empirical work is one as it is shown from diagnostic test (see appendix 3 and 7). The SC, HQ and AIC test depicts similar pattern with F-test confirming the preference of order one which states that the VAR model with lowest value of SC, HQ and AIC shows the better integration at that order. There is problem of normality of the disturbance term. There is no serial correlation and heteroscedasticity problem (see appendix 2). Hence understanding this we proceed to the next step.

Once the order of the VAR is determined the next step is to determine co-integration rank. This tells that there is co-integration among the variables. The trace test suggests that the null hypothesis of zero co-integration relationship can be rejected in favour of one co-integrating vector (see appendix 3 ).

The next step is identification of unique beta coefficients by imposing a rank restriction in the co-integration space to obtain unique relationship (see Appendix 4). Finally hypothesis testing on the significance of coefficients of the variables in the long run structural equation is conducted. This helps to identify the long run determinant variables in the model. From the likelihood ratio statistics, rainfall and labour are the determinant of agricultural GDP in Ethiopia (Appendix 5). Using Granger causality test, price is also in influential variables for agricultural GDP (Appendix 7). Hence in the long-run structural equations labour, price and rainfall are the most important variables spanning the relationships. The capital stock and institutions are not influential variables in the long-run structural equations.

The test result suggests our co-integrating vector is unique and in terms of the structural long run relationship, some variables are significant variables in explaining the dependent variables. The next step is testing for weak erogeneity (Appendix 6). This test is providing an indicator to separate endogenous (dependent) and exogenous (independent) variables as well as the Granger causality of each variable. Labour, rainfall and institutions are exogenous variables whereas the agricultural GDP is endogenous for the model. Based on Granger causality test labour and price are significant variables that Granger cause the dependent variable agricultural GDP. Hence the 
model is valid for the explanatory variables labour, rainfall and price.

Table 2 Estimation Results Short run: Dependent Variable (DY)

\begin{tabular}{llll}
\hline Variables & Coefficient & t-value & t-prob \\
\hline DY_2 & -0.364674 & -2.79 & 0.009 \\
DL_2 & 0.488944 & 3.53 & 0.001 \\
DRF & 0.000298824 & 4.18 & 0.000 \\
DP & -0.0983301 & -1.13 & 0.265 \\
S & 0.0439182 & 2.98 & 0.005 \\
\hline
\end{tabular}

Diagnostic test

AR 1-2 test: $\quad \mathrm{F}(2,31)=0.10158[0.9037]$

ARCH 1-1 test: $\mathrm{F}(1,31)=15.152[0.0005]^{* *}$

Normality test: $\mathrm{Chi}^{\wedge} 2(2)=10.917[0.0043]^{* *}$

hetero test: $\quad \mathrm{F}(9,23)=0.33948[0.9519]$

hetero-X test: $\quad F(19,13)=0.13564[0.9999]$

RESET test: $\quad F(1,32)=1.4821[0.2323]$

Source: Own Results (2017)

The Engle Granger causality modeling shows that agricultural labor and Price of agricultural goods to nonagricultural goods Granger Cause agricultural productivity, Capital inputs in agriculture and Price of agricultural goods to non-agricultural goods Granger Cause agricultural labor, Rainfall Granger Cause ratio of Price of agricultural goods to non-agricultural goods and finally ratio of Price of agricultural goods to non-agricultural goods Granger Cause institutional capability (Appendix 7).

Table 3 Estimation result long run: dependent variable (Y)

\begin{tabular}{|c|c|c|c|}
\hline Variable & Coefficient & t-value & t-prob \\
\hline Y_1 & 0.735024 & 5.45 & 0.000 \\
\hline $\mathrm{Y}_{-}^{-} 2$ & -0.389108 & -2.90 & 0.007 \\
\hline Constant & 4.64121 & 4.77 & 0.000 \\
\hline L_2 & 0.485943 & 3.91 & 0.000 \\
\hline K_2 & -0.0844312 & -2.50 & 0.018 \\
\hline $\mathrm{R} \overline{\mathrm{F}}$ & 0.000259193 & 3.14 & 0.004 \\
\hline RF_1 & -0.000194553 & -2.16 & 0.039 \\
\hline$P_{-} \overline{1}$ & 0.203977 & 3.51 & 0.001 \\
\hline $\mathrm{S}_{-}^{-} 1$ & 0.0369512 & 1.60 & 0.12 \\
\hline $\mathrm{R}^{\wedge} 2$ & 0.97437 & $\mathrm{~F}(8,30)=$ & $142.6[0.000]^{* *}$ \\
\hline \multirow{4}{*}{\multicolumn{4}{|c|}{$\begin{array}{l}\text { AR 1-2 test: } \quad \mathrm{F}(2,28)=2.2147[0.1280] \\
\text { ARCH 1-1 test: } \quad \mathrm{F}(1,28)=7.6205[0.0101]^{*} \\
\text { Normality test: } \mathrm{Chi} \wedge 2(2)=19.751[0.0001]^{* *} \\
\text { hetero test: } \quad \mathrm{F}(15,14)=1.0433[0.4708]\end{array}$}} \\
\hline & & & \\
\hline & & & \\
\hline & & & \\
\hline RESET test: & $\mathrm{F}(1,29)=0.28761[0.5958]$ & & \\
\hline
\end{tabular}

Source: Own Results (2017)

Once the co-integrating vectors are identified from the agriculture GDP (LYAG) VAR, an error correction model consisting of differenced endogenous and exogenous variables and error correction terms derived from the co-integrated VARs is estimated. The short run and long run co-integrating equation by VECM is presented as follows. In doing so several attempt is made to get the congruent vector error correction model. The final model is selected using coefficient of determination and significant of the co-integrating equation coefficient. The coefficient of determination tells that the error correction model is best fitted for the variables considered.

Due to the inherent problem of heteroscedastic and autocorrelation in timeseries econometrics, adjustment using Prais-Winsten Cochrane-Orcutt regression on estimation the production function of agriculture was conducted (see table 4). Ethiopian Agricultural production exhibits decreasing return to scale ((0.76) implying that a proportionate increase in inputs provide a lesser proportionate increase in output of agriculture. The higher elasticity of labor $((0.5)$ than capital $((0.26)$ employed in agriculture implied that there is scope for input substitution through irrigation and higher productive machineries both at smallholder and large farms. 
Table 4. Prais-Winsten Cochrane-Orcutt regression

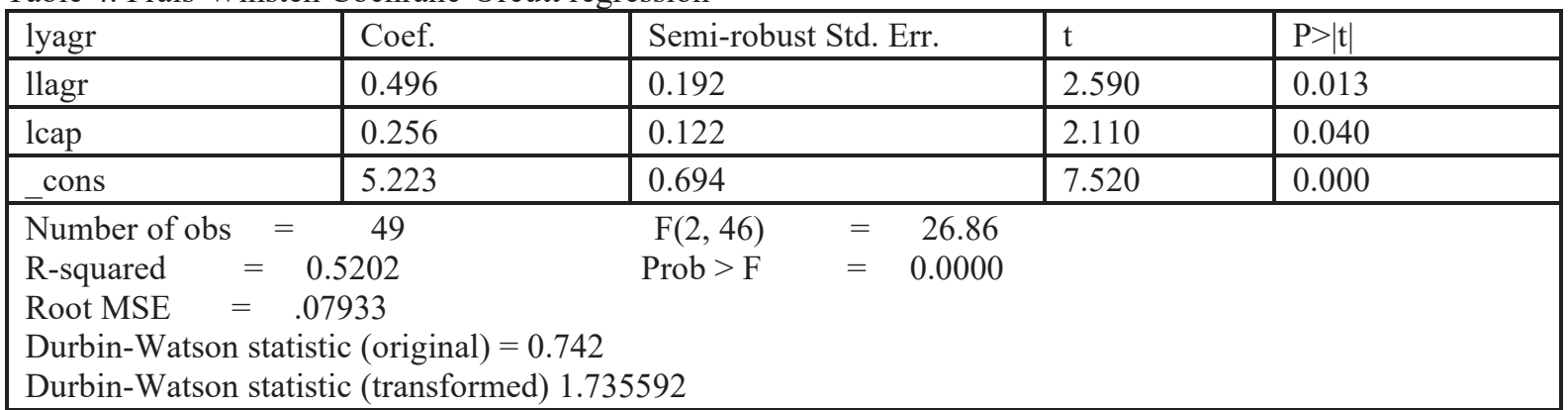

Source: Model Results (2017)

From the vector error correction model result, the coefficient of the co-integrating equation tells that about 45 percent of disequilibrium corrected each year by change in aggregate agricultural production. The overall performance of the model is well fitted, because the $64 \%$ of total variation of the dependent variable is explained by the independent variables included in the model. Moreover, the model selection criteria indicated the model is adequate to represent the real world and manageable to predict agricultural production behavior in Ethiopia.

Table 4 Cointegrating Equation:CE1

\begin{tabular}{lccc}
\hline Variable & Coefficient & Standard error & t-value \\
\hline L $(-1)$ & -0.0161987 & 0.0381 & -0.425 \\
K $(-1)$ & 0.332341 & -1.7958 & 0.18507 \\
RF(-1) & 35.10722 & -11.1944 & $3.13^{* * *}$ \\
$\mathrm{P}(-1)$ & 19.69533 & -4.65063 & $4.24^{* * *}$ \\
$\mathrm{~S}(-1)$ & -6.38214 & -2.09028 & $-3.05^{* * *}$ \\
$\mathrm{C}$ & -279.951 & & \\
\hline
\end{tabular}

*** implies significant at 1\% probability level

Source: Model Results (2017)

The Vector error correction estimate depicts that Ethiopian agricultural GDP in the short run is dependent up on agricultural labour employed, rainfall, lagged agricultural production and relative price. The elasticity of price in the short run is positive and negative in the long run. This implied that it is an incentive in the long run and sluggish in the short run. This is with consistent with the theory behind market signal for improving agricultural productivity. In the long run, real agricultural production and productivity are determined by institutional capability, relative price ratio of agricultural to non-agricultural goods and services and rain fall as a vagaries of nature.

Table 5 Vector Error correction estimate: Dependent variable (DLYAG)

\begin{tabular}{|l|c|c|c|}
\hline Variable & Coefficient & Standard error & t-value \\
\hline CointEq1 & -0.454 & -0.190 & $-2.396^{* * *}$ \\
\hline D(LYAGR(-1)) & 0.484 & -0.225 & $2.151^{* *}$ \\
\hline D(LYAGR(-2)) & -0.494 & -0.194 & $-2.555^{* * *}$ \\
\hline D(LYAGR(-3)) & 0.010 & -0.210 & 0.046 \\
\hline D(LLAGR(-1)) & -0.584 & -0.265 & $-2.204^{* *}$ \\
\hline D(LLAGR(-2)) & -0.206 & -0.290 & -0.709 \\
\hline D(LLAGR(-3)) & -0.298 & -0.271 & -1.100 \\
\hline D(LCAPAG(-1)) & 0.016 & -0.142 & 0.110 \\
\hline D(LCAPAG(-2)) & -0.062 & -0.180 & -0.344 \\
\hline D(LCAPAG(-3)) & 0.117 & -0.194 & 0.601 \\
\hline D(LRF(-1)) & -0.578 & -0.159 & $-3.628^{* * *}$ \\
\hline D(LRF(-2)) & -0.247 & -0.141 & $-1.753^{*}$ \\
\hline D(LRF(-3)) & -0.140 & -0.118 & -1.195 \\
\hline D(PATOPNA(-1)) & -0.033 & -0.202 & -0.165 \\
\hline D(PATOPNA(-2)) & -0.305 & -0.183 & $-1.670^{*}$ \\
\hline D(PATOPNA(-3)) & -0.114 & -0.172 & -0.664 \\
\hline D(S(-1)) & 0.005 & -0.062 & 0.081 \\
\hline D(S(-2)) & 0.025 & -0.058 & 0.432 \\
\hline D(S(-3)) & 0.081 & -0.057 & 1.420 \\
\hline C & 0.108 & -0.047 & $2.331^{* *}$ \\
\hline R-squared & 0.640 & & \\
\hline Adj. R-squared & 0.352 & & \\
\hline
\end{tabular}




\begin{tabular}{|l|c|l|l|}
\hline Variable & Coefficient & Standard error & t-value \\
\hline Sum sq. resids & 0.126 & & \\
\hline S.E. equation & 0.071 & & \\
\hline F-statistic & 2.222 & & \\
\hline Log likelihood & 70.413 & & \\
\hline Akaike AIC & -2.148 & & \\
\hline Schwarz SC & -1.314 & & \\
\hline Mean dependent & 0.046 & & \\
\hline S.D. dependent & 0.088 & & \\
\hline
\end{tabular}

$*, * *, * * *$ implies significant at $10 \%, 5 \%$ and $1 \%$ probability level

Source: Model Results (2017)

From this empirical estimate it can be interpreted that Price is very sluggish to be an incentive in Ethiopian agriculture GDP. In fact the majority of smallholder agriculture in Ethiopia is not producing for market rather for home consumption. This is possibly because of the reason that institutions are not favourable for functioning of markets both in open economy regime as well as in command economy regime. This tells us that there is no structural change in the economy. Agriculture GDP is mainly dependent on labour, price ratio and vagaries of nature in the short run. When we see further the agricultural labour, it is mainly composed of unskilled labour. The variables are co-integrated with polynomial rank ranging from 1 to 5 with significant contribution to agricultural GDP. The results in this study show that Ethiopian agriculture is mainly dependent on vagaries of nature. Therefore relying on the majority of unskilled labour and nature, Ethiopia could not be out of the poverty trap. To circumvent the condition Ethiopia should have to invest on human capital and reduce its reliance on nature by developing irrigation which could boost agricultural production and productivity.

\section{CONCLUDING REMARKS}

In this empirical work, the aggregate production function of agricultural sector in Ethiopia is estimated using vector error correction model. The estimation result confirms that most of the variables are co-integrated of various ranks. There is an inverse impact of institutional transformation from public to private ownership of resources in improving agricultural growth the long run but not in the short run. Short run sources of Agricultural productivity growth-Rainfall, Labor, previous harvest and price while Long run sources of Agricultural productivity growthinstitutional capability, rainfall and price. There are minimal productivity changes- decreasing RTS (0.76) mainly attributable to labor (0.5) and limited capital (0.26). Vector error correction modeling of the sector shows that the Ethiopian agricultural sector depicted that Main sources of growth depend on vagaries of nature. The Productivity improvement emerging mainly from labor. Finally, forecasting of the agricultural production and its associated sources of growth has been made to provide solution in future values. To circumvent the poverty trap in the country, therefore, the government needs to invest on human capital and irrigation development to reduce its dependence on vagaries of nature. Improving on labor productivity through quality, affordable and equitable education. Moreover, competent private-public partnership in increasing the capability of institutions on coordination and cooperation of resource use is also vital. This suggests for proper delegation of power and balance on efficiency and equity.

\section{REFERENCES}

Acemoglu, D., S. Johnson, and J.A. Robinson, 2001. The Colonial Origins of Comparative Development: An Empirical Investigation, American Economic Review.

Acemoglu, D., S. Johnson. and J.A. Robinson, 2002. Reversal of Fortune: Geography and Institutions in the Making of the Modern World Income Distribution, Quarterly Journal of Economics.

Alemayehu Geda and Daniel Zerfu, 2008. Estimating Aggregate Production Function with I(2) Capital Stock. Department of Economics, Addis Ababa University and Department of Economics, Gothenburg University

Alemayehu Geda, Njuguna Ndung'u, Daniel Zerfu. (2008), Applied Time Series Econometrics: A Practical Guide for Macroeconomic Researchers with a Focus on Africa. Addis Ababa University, African Economic Research Consortium and Central Bank of Kenya.

Dickey, D.A. and W.A.Fuller (1981), "Likelihood Ratio Statistics for Autoregressive Time Series with a Unit Root", Econometrica, Vol.49, 1057-1072.

Engel, R.F. and C.W.J. Granger (1987). "Co-integration and Error-Correction: Representation, Estimation and Testing', Econometrica, 55:251-76.

Glaeser, E. and A. Shleifer, 2002. Legal Origins', Quarterly Journal of Economics, November.

Johansen, S. (1991). "Estimation and Hypothesis Testing of Cointegration Vectors in Gaussian Vector Autoregressive Models". Econometrica, 59(6): 1551-1580.

Johansen, S. and K. Juselius (1990). "Maximum Likelihood Estimation and Inference on Cointegration: With 
Applications to the Demand for Money". Oxford Bulletin of Economics and Statistics, 52(2): 169-210.

Mankiw, G.N., D. Romer, and D.N. Weil, 1992. A Contribution to the Empirics of Economic Growth. The Quarterly Journal of Economics, 107:2, pp. 407-37.

North, D.C., 1990. Institutions, Institutional Change and Economic Performance, Cambridge: Cambridge University Press.

North, D.C., 1991. Institutions, Journal of Economic Perspectives, Winter.

Olson, M., 2000. Power and Prosperity: Outgrowing Communist and Capitalist Dictatorships, New York: Basic Books.

Rodrik, D., 2003. In Search of Prosperity: Analytic Narratives on Economic Growth, Princeton: Princeton University Press.

Romer, P.M., 1986. Increasing Returns and Long-Run Growth', Journal of Political Economy.

Shaikh, A., 1974. Laws of Production and Laws of Algebra: The Humbug Production Function. Review of Economics and Statistics, 56(1): 115-20.

Temple, J., 2008. Aggregate production functions and growth economics. Department of Economics, University of Bristol 8 Woodland Road, Bristol BS8 1TN, UK and CEPR

World Bank, 1997. The State in a Changing World, Oxford: Oxford University Press.

\section{APPENDICES}

Appendix 1 Unrestricted VAR: 1966 to 2014

URF equation for: $Y$

\begin{tabular}{lccccc} 
& Coefficient & Std.Error & \multicolumn{2}{c}{ t-value } & t-prob \\
Y_1 & 0.537222 & 0.1691 & 3.18 & 0.003 \\
L_1 & 0.248094 & 0.1509 & 1.64 & 0.110 \\
K_1 & -0.0167960 & 0.03816 & -0.440 & 0.663 \\
RF_1 & -0.000129281 & 0.0001181 & -1.09 & 0.282 \\
P_1 & 0.141540 & 0.07610 & 1.86 & 0.072 \\
S_1 & 0.0405989 & 0.02788 & 1.46 & 0.155 \\
Constant & $\mathrm{U}$ & 3.40133 & 1.140 & 2.98 & 0.005
\end{tabular}

F-test on regressors except unrestricted: $\mathrm{F}(36,125)=35.94[0.0000] * *$

F-tests on retained regressors, $\mathrm{F}(6,28)=$

$\begin{array}{lllr}\mathrm{Y} \_1 & 3.68140[0.008]^{* *} & \mathrm{~L}_{-} 1 & 5.03772[0.001]^{* *} \\ \mathrm{~K} \_1 & 63.9640[0.000]^{* *} & \mathrm{RF}_{-} 1 & 3.30331[0.014]^{*} \\ \mathrm{P} \_1 & 7.55993[0.000]^{* *} & \mathrm{~S}_{-} 1 & 15.2480[0.000]^{* *}\end{array}$

Constant U $3.25418[0.015]^{*}$

Progress to date

Model T p log-likelihood SC HQ AIC

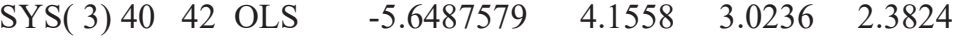

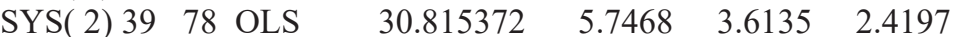

SYS( 1) 38114 OLS $\quad 66.635419 \quad 7.4056 \quad 4.2408 \quad 2.4929$

Source: Model Results (2017)

Appendix 2 Diagnostic Test statistics

Testing for Vector error autocorrelation from lags 1 to 2

$\mathrm{Chi}^{\wedge} 2(72)=91.617[0.0593]$ and $\mathrm{F}$-form $\mathrm{F}(72,92)=1.1001[0.3310]$

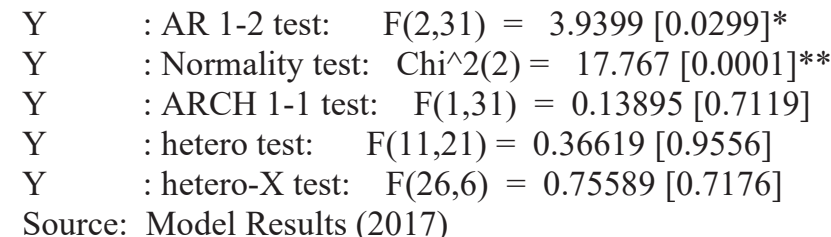


Appendix 3 I(1) cointegration analysis, 1966 to 2014

eigenvalue loglik for rank

$$
-55.569660
$$

$\begin{array}{llll}0.63158 & -35.59930 & 1\end{array}$

$\begin{array}{lll}0.45410 & -23.49304 & 2\end{array}$

$\begin{array}{lll}0.35344 & -14.77120 & 3\end{array}$

$\begin{array}{lll}0.26016 & -8.744813 & 4\end{array}$

$\begin{array}{lll}0.12235 & -6.134779 & 5\end{array}$

$0.024008 \quad-5.648758 \quad 6$

H0:rank $<=$ Trace test pvalue

$0 \quad 99.842[0.024] *$

$1 \quad 59.901[0.239]$

$2 \quad 35.689[0.417]$

$3 \quad 18.245[0.558]$

$4 \quad 6.1921[0.677]$

$5 \quad 0.97204[0.324]$

Source: Model Results (2017)

Appendix 4 Cointegrated VAR 1966 to 2014

Number of lags used in the analysis: 1

beta

Y $\quad 1.0000$

L $\quad-1.0402$

K $\quad 0.10587$

RF $\quad-0.0014069$

$\mathrm{P} \quad 0.19346$

S $\quad 0.075092$

alpha

Y 0.16652

L $\quad 0.28028$

K $\quad 0.0060513$

RF 439.93

$\mathrm{P} \quad-0.058618$

S $\quad-0.58915$

Reduced form beta

L $\quad 1.0402$

K $\quad-0.10587$

RF $\quad 0.0014069$

$\mathrm{P} \quad-0.19346$

S $\quad-0.075092$

Appendix 5 General cointegration restrictions on beta parameters:

Y \&6=0; LR test of restrictions: $\mathrm{Chi}^{\wedge} 2(1)=4.5519$ [0.0329]*

L \& $7=0$; LR test of restrictions: $\mathrm{Chi}^{\wedge} 2(1)=7.1067[0.0077]^{* *}$

$\mathrm{K} \& 8=0$; LR test of restrictions: $\mathrm{Chi}^{\wedge} 2(1)=1.8596[0.1727]$

Rf \&9=0; LR test of restrictions: $\mathrm{Chi}^{\wedge} 2(1)=13.661[0.0002]^{* *}$

P \& 10=0; LR test of restrictions: $\mathrm{Chi}^{\wedge} 2(1)=1.1349$ [0.2867]

$\mathrm{S} \& 11=0$; LR test of restrictions: $\mathrm{Chi}^{\wedge} 2(1)=2.1759$ [0.1402]

Appendix 6 General cointegration restrictions on alpha parameters:

L \& $1=0$; LR test of restrictions: $\mathrm{Chi}^{\wedge} 2(1)=10.582[0.0011]^{* *}$

$\mathrm{K} \& 2=0$; LR test of restrictions: $\mathrm{Chi}^{\wedge} 2(1)=0.0035608$ [0.9524]

RF \& 3 $=0$; LR test of restrictions: $\mathrm{Chi}^{\wedge} 2(1)=7.3246[0.0068]^{* *}$

$\mathrm{P} \& 4=0$; LR test of restrictions: $\mathrm{Chi}^{\wedge} 2(1)=0.18587$ [0.6664]

$\mathrm{S} \& 5=0$; LR test of restrictions: $\mathrm{Chi}^{\wedge} 2(1)=4.5424[0.0331]^{*}$

Source: Model Results (2017) 
Appendix 7 Pairwise Granger Causality Tests

\begin{tabular}{|c|c|c|c|}
\hline Null Hypothesis: & Obs & F-Statistic & Prob. \\
\hline LLAGR does not Granger Cause LYAGR & 47 & 2.79 & 0.05 \\
\hline LYAGR does not Granger Cause LLAGR & & 0.12 & 0.95 \\
\hline LCAPAG does not Granger Cause LYAGR & 47 & 0.98 & 0.41 \\
\hline LYAGR does not Granger Cause LCAPAG & & 0.34 & 0.79 \\
\hline LRF does not Granger Cause LYAGR & 47 & 1.38 & 0.26 \\
\hline LYAGR does not Granger Cause LRF & & 0.82 & 0.49 \\
\hline PATOPNA does not Granger Cause LYAGR & 47 & 4.35 & 0.01 \\
\hline LYAGR does not Granger Cause PATOPNA & & 1.06 & 0.38 \\
\hline S does not Granger Cause LYAGR & 47 & 0.75 & 0.53 \\
\hline LYAGR does not Granger Cause S & & 0.67 & 0.57 \\
\hline LCAPAG does not Granger Cause LLAGR & 47 & 6.71 & 0.00 \\
\hline LLAGR does not Granger Cause LCAPAG & & 0.40 & 0.75 \\
\hline LRF does not Granger Cause LLAGR & 47 & 0.90 & 0.45 \\
\hline LLAGR does not Granger Cause LRF & & 0.54 & 0.66 \\
\hline PATOPNA does not Granger Cause LLAGR & 47 & 4.09 & 0.01 \\
\hline LLAGR does not Granger Cause PATOPNA & & 0.10 & 0.96 \\
\hline S does not Granger Cause LLAGR & 47 & 0.74 & 0.54 \\
\hline LLAGR does not Granger Cause S & & 0.66 & 0.58 \\
\hline LRF does not Granger Cause LCAPAG & 47 & 0.40 & 0.75 \\
\hline LCAPAG does not Granger Cause LRF & & 0.43 & 0.73 \\
\hline PATOPNA does not Granger Cause LCAPAG & 47 & 0.56 & 0.64 \\
\hline LCAPAG does not Granger Cause PATOPNA & & 2.21 & 0.10 \\
\hline S does not Granger Cause LCAPAG & 47 & 1.36 & 0.27 \\
\hline LCAPAG does not Granger Cause S & & 1.88 & 0.15 \\
\hline PATOPNA does not Granger Cause LRF & 47 & 2.06 & 0.12 \\
\hline LRF does not Granger Cause PATOPNA & & 6.29 & 0.00 \\
\hline S does not Granger Cause LRF & 47 & 0.39 & 0.76 \\
\hline LRF does not Granger Cause $\mathrm{S}$ & & 0.90 & 0.45 \\
\hline S does not Granger Cause PATOPNA & 47 & 1.32 & 0.28 \\
\hline PATOPNA does not Granger Cause S & & 4.09 & 0.01 \\
\hline
\end{tabular}

Source: Model Results (2017)

Appendix 8 Johansen cointegration test with Lags interval: 1 to 1

\begin{tabular}{ccccc}
\hline Eigenvalue & $\begin{array}{c}\text { Likelihood } \\
\text { Ratio }\end{array}$ & $\begin{array}{c}\text { 5 Percent } \\
\text { Critical Value }\end{array}$ & $\begin{array}{c}\text { 1 Percent } \\
\text { Critical Value }\end{array}$ & $\begin{array}{c}\text { Hypothesized } \\
\text { No. of CE(s) }\end{array}$ \\
\hline 0.689368 & 123.4846 & 94.15 & 103.18 & None ** \\
0.633608 & 77.88791 & 68.52 & 76.07 & At most $1 * *$ \\
0.421668 & 38.72987 & 47.21 & 54.46 & At most 2 \\
0.243274 & 17.37316 & 29.68 & 35.65 & At most 3 \\
0.137158 & 6.501742 & 15.41 & 20.04 & At most 4 \\
0.019005 & 0.748323 & 3.76 & 6.65 & At most 5 \\
\hline
\end{tabular}

$*(* *)$ denotes rejection of the hypothesis at $5 \%,(1 \%)$ significance level

L.R. test indicates 2 cointegrating equation(s) at 5\% significance level

Source: Model Results (2017)

Appendix 9 Normalized Cointegrating Coefficients:

$\begin{array}{ccccccc}\mathrm{Y} & \mathrm{L} & \mathrm{K} & \mathrm{RF} & \mathrm{P} & \mathrm{S} & \mathrm{C} \\ 1.000000 & 1.046362 & 0.154629 & 0.007132 & -1.918424 & -0.587580 & -17.75946 \\ & (2.51940) & (0.30791) & (0.01043) & (2.63998) & (0.79647) & \end{array}$

Log likelihood $\quad-8.128582$

Source: Model Results (2017) 
Appendix 10 Definition and measurement of variables

\begin{tabular}{l} 
Variable \\
\hline LYAGR (Y) \\
LLAGR (L) \\
LCAPAG(K) \\
LRF(RF) \\
PatoPna (P) \\
S
\end{tabular}

Definition and measurement agricultural GDP at time $t$ in Birr,

agricultural labour employed in man days at time $\mathrm{t}$

capital stock in Birr at time $t$

rainfall in millilitre at time $\mathrm{t}$

price of agricultural product to price of non-agricultural product at time $t$

$\mathrm{S}$ Institution dummy, $=1$ if open economy and zero otherwise

L indicate natural logarithmic

Appendix 11. Forecasting of key variables Response of LYAGR to Cholesky One S.D. Innovations

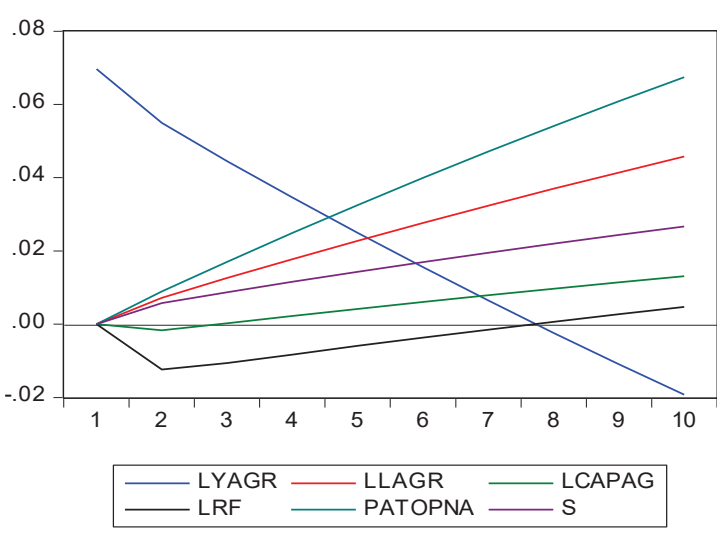

Response of LCAPAG to Cholesky One S.D. Innovations

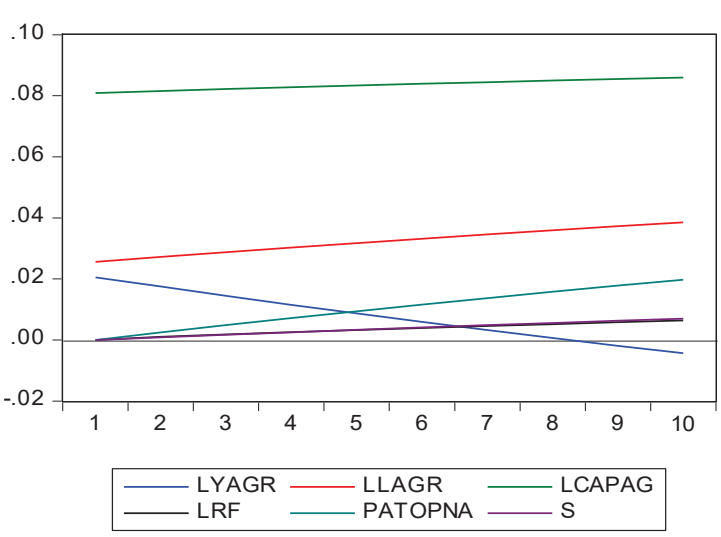

Response of PATOPNA to Cholesky One S.D. Innovations

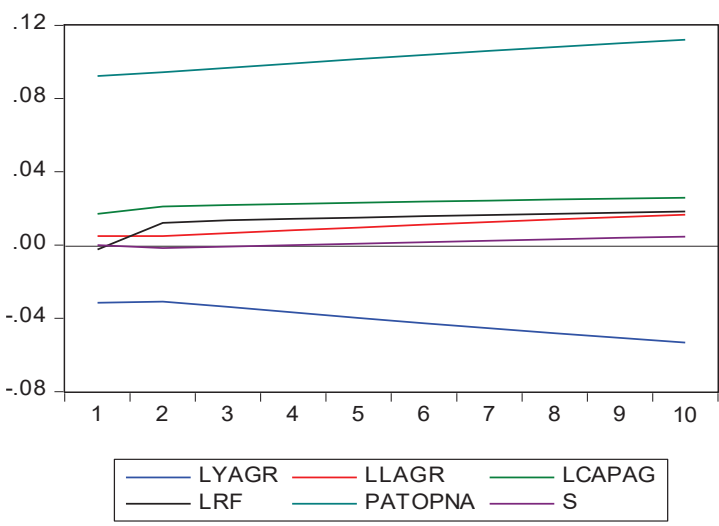

Response of LLAGR to Cholesky One S.D. Innovations

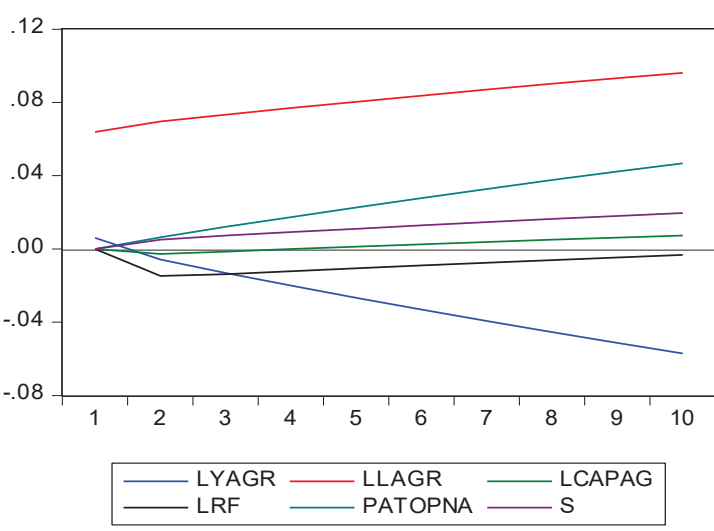

Response of LRF to Cholesky One S.D. Innovations

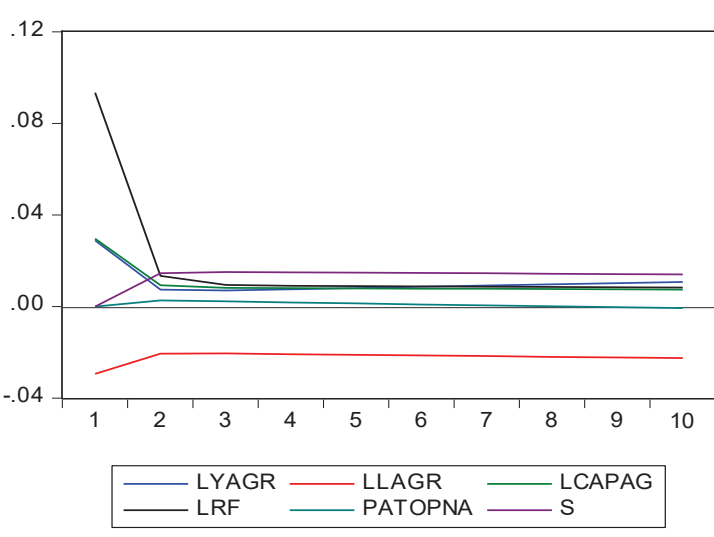

Response of S to Cholesky One S.D. Innovations

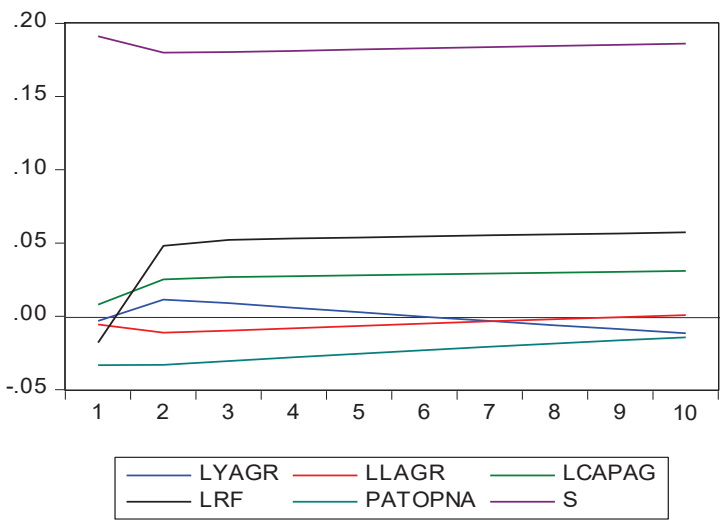

